\title{
Quantifying spatial heterogeneity in herbage mass and consumption in pastures
}

\author{
MASAHIKO HIRATA
}

Author is associate professor, Grassland and Animal Production Division, Faculty of Agriculture, Miyazaki University, Miyazaki 889-2192, Japan. E-mail: a02202u@cc.miyazaki-u.ac.jp

\begin{abstract}
A sward-based technique for quantifying the spatial heterogeneity in herbage mass and consumption was developed and tested in a bahia grass (Paspalum notatum Flügge) pasture grazed by cattle. For five, 2-day grazing periods from May to October, pre- and post-grazing herbage masses were nondestructively estimated with an electronic capacitance probe at 182, 50 $x 50 \mathrm{~cm}$ locations along 2 permanent line transects. At the same time, undisturbed herbage accumulation during grazing was measured inside exclosures and the results used to estimate accumulation under grazing at each location. Estimation of herbage mass was relatively good; $R^{2}=0.88$ to 0.98 . Spatial heterogeneity in herbage mass and the stability of the spatial pattern were well quantified. The pattern of spatial heterogeneity observed early in the grazing season remained quite stable for 5 months until the late grazing season. Spatial heterogeneity in the rate of defoliation was also well quantified in spite of some negative values. The technique is of potential value for quantifying the spatial heterogeneity in herbage mass and consumption by animals in grazed pastures, though further studies are necessary for testing the applicability of the technique to pastures of other plant species or of multiple species.
\end{abstract}

Key Words: electronic capacitance probe, patch grazing, patch stability, rate of defoliation, spatial pattern, Paspalum notatum

Vegetation of grazing systems is spatially heterogeneous (Vallentine 1990). Even in virtually monospecific pastures, vegetation forms a mosaic in which short, heavily grazed patches having small herbage mass alternate with tall, ungrazed or lightly grazed patches having large herbage mass, with a transitional zone of intermediate height, utilization and mass (Illius et al. 1987, Liu and Hirata 1995, Hirata and Fukuyama 1997, Cid and Brizuela 1998, Hirata 1998).

It is well known that such heterogeneity is created and maintained by selective (spatially heterogeneous) grazing by animals: i.e., animals visit and graze heavily grazed patches more frequently than the surrounding patches (Illius et al. 1987), preferring the higher digestibility and nitrogen concentration in heavily grazed patches (Illius et al. 1987, Cid and Brizuela 1998).

The author is grateful to Mr. Takuya Iwamoto, Mr. Waka Otozu and Mr. Daisuke Kiyota for field assistance, and to Mr. Kiichi Fukuyama and Mr. Shirou Kuroki of the Sumiyoshi Livestock Farm for pasture and animal management.

Manuscript accepted 6 Sept. 1999.

\section{Resumen}

Se desarrollo una técnica basada en la pradera para cuantificar la heterogeneidad espacial de la masa de forraje y el consumo, y se probo en una pradera de "Bahia grass"(Paspalum notatum Flügge) apacentada por bovinos. En 5 periodos de apacentamiento de 2 días comprendidos entre mayo y octubre, se estimo la masa de forraje antes y después del apacentamiento mediante el método no destructivo de la sonda de capacitor electrónico, la estimación se realizó en 182 cuadrantes de 50 x $50 \mathrm{~cm}$ localizados en 2 transectos de línea permanentes. Al mismo tiempo se midió la acumulación de forraje sin disturbio ocurrida durante el apacentamiento, lo cual se hizo dentro de exclusiones y los resultados se utilizaron para estimar la acumulación de forraje bajo apacentamiento en cada localidad. La estimación de forraje fue relativamente buena; $R^{2}=0.88$ a 0.98 . La heterogeneidad espacial de la masa de forraje y la estabilidad del patrón espacial se cuantificaron bien. El patrón de la heterogeneidad espacial observado al inicio de la estación de apacentamiento permaneció muy estable durante 5 meses hasta finales de la estación de apacentamiento. La heterogeneidad espacial de la tasa de defoliación también fue bien cuantificada a pesar de algunos valores negativos. La técnica es de valor potencial para cuantificar la heterogeneidad espacial de la masa de forraje y consumo por animales en praderas apacentadas, aunque son necesarios mas estudios para probar la aplicabilidad de esta técnica en praderas de otra especies vegetales o praderas con mas de una especie.

However, few workers have measured the utilization of individual patches in terms of herbage consumption or intake. Frequent grazing of heavily grazed patches does not necessarily mean that herbage consumption in these patches is greater than that in other patches, because low herbage availability of heavily grazed patches may limit the intake rate of animals. Since herbage consumption, as well as herbage accumulation, is a factor determining the changes in herbage mass, information on the herbage consumption in individual patches in a pasture is important in understanding the mechanisms behind patch development and stability.

Hirata and Fukuyama (1997) developed a sward-based technique for estimating herbage consumption by grazing animals at a small patch scale and used the technique on a bahia grass (Paspalum notatum Flügge) pasture grazed by cattle. An electronic capacitance probe was used to estimate herbage mass in a number of fixed locations $(50 \times 50 \mathrm{~cm})$ along permanent transects before and after grazing, and herbage consumption in each location was estimated from the change in the herbage mass with grazing. 
However, the results had limitations because the herbage consumption was estimated without taking the herbage accumulation during grazing into account. The aims of the present study were to overcome such limitations and examine the usefulness of the technique for quantifying the spatial heterogeneity in herbage mass and consumption in a grazed pasture.

\section{Materials and Methods}

\section{Study site and grazing and pasture management}

The same paddock as in the previous study (Hirata and Fukuyama 1997), i.e., a 1.1-ha paddock of a bahia grass pasture at the Sumiyoshi Livestock Farm $\left(31^{\circ} 59^{\prime} \mathrm{N}\right.$, $\left.131^{\circ} 28^{\prime} \mathrm{E}\right)$, Faculty of Agriculture, Miyazaki University, Japan, was used. The paddock was 1 of 5 paddocks rotationally grazed by Japanese Black Cows. The vegetation was highly dominated by bahia grass. According to the measurements in the previous year (1995), bahia grass accounted for $87 \%$ of herbage mass (above a $3 \mathrm{~cm}$ height; on a dry matter (DM) basis) in May, and 97 to $100 \%$ from June to October (Hirata and Fukuyama 1997).

During the grazing season (MayOctober) of 1996, the paddock was grazed by 28 to 32 animals with a 2 to 6 -day duration at intervals of 11 to 37 days. The total duration of grazing periods was 23 days. The annual fertilization rates in the paddock were $77 \mathrm{~kg} \mathrm{~N}$ (split application in

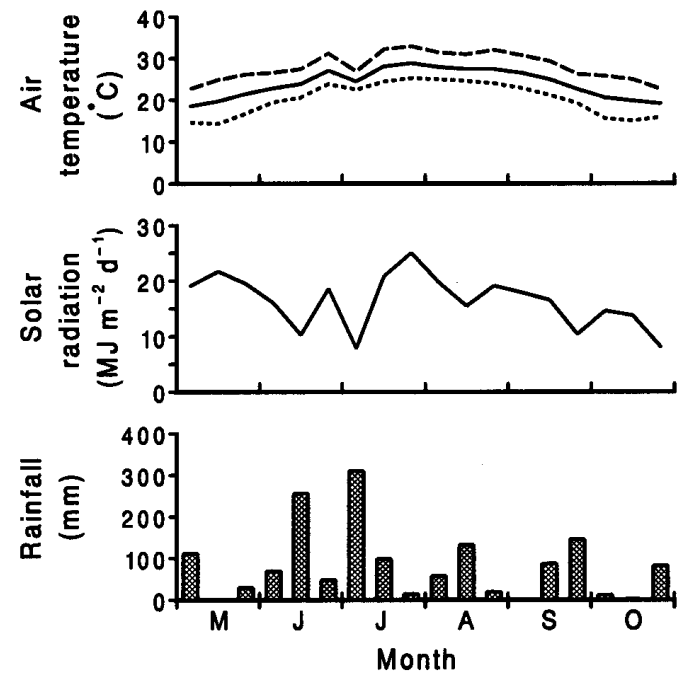

Fig. 1. Ten or 11 day average of maximum (- - - -), mean (-), and minimum $(\cdots \cdot \cdot)$ air temperatures, daily total shortwave solar radiation, and 10 or 11 day totals of rainfall during the study period.
March and August), $20 \mathrm{~kg} \mathrm{P}$ (March) and $30 \mathrm{~kg} \mathrm{~K}$ (March) ha ${ }^{-1}$. The meteorological conditions during the study are shown in Fig. 1 .

\section{Measurement periods}

Five, 2-day periods at approximately monthly intervals were selected from the rotational grazing periods as Periods 1 to 5 (Table 1), representing the first 2 days of a grazing period. Pre- and post-grazing herbage mass, herbage accumulation and rate of defoliation were estimated for these 5 selected periods. The duration of 2 days was selected to ensure enough reduction in herbage mass by grazing for detection

\section{Electronic capacitance probe}

An electronic capacitance probe (PastureProbe $^{\mathrm{TM}}$, Mosaic Systems Ltd., New Zealand) was used to estimate herbage mass. PastureProbe ${ }^{\mathrm{TM}}$ is a single probe capacitance meter, which is light in weight and highly portable (Hirata et al. 1993). There have been many reports evaluating electronic capacitance probes, and results indicate that the single-probe capacitance meter is at least as good and more labor saving than any other alternatives for indirect herbage mass measurement (Frame 1993). The accuracy of PastureProbe $^{\mathrm{TM}}$ in estimating herbage mass of bahia grass swards was tested by Hirata et al. (1993). Because the relationship between herbage mass and corrected meter reading of electronic capacitance probe with a capacitance probe.
Table 1. Outlines of selected grazing periods for measurements.

\begin{tabular}{llcc}
\hline \hline Period & Date & $\begin{array}{c}\text { Number of } \\
\text { cows }\end{array}$ & $\begin{array}{c}\text { Mean } \\
\text { liveweight }\end{array}$ \\
\hline & & & $\left(\mathrm{kg} \mathrm{cow}^{-1}\right)$ \\
1 & 25-26 May & 28 & 462 \\
2 & 29-30 Jun. & 28 & 454 \\
3 & 3-4 Aug. & 28 & 446 \\
4 & 14-15 Sep. & 29 & 452 \\
5 & 26-27 Oct. & 32 & 468 \\
\hline
\end{tabular}

(CMR) is known to vary with such factors as sward type, season of growth (developmental stage), herbage moisture content and ratio of green to dead material (Frame 1993, Hirata et al. 1993), and was anticipated to vary also with grazing, calibration equations were developed separately for individual measurement occasions as described later.

\section{Pre- and post-grazing herbage mass}

Horizontal distribution of herbage mass was measured both at the beginning and the end of the 5 selected periods, i.e., on 10 occasions. On each occasion, CMR was measured at 1-m intervals along 2 permanent line transects crossing the paddock. Each transect was $90 \mathrm{~m}$ long and, therefore, the CMR was determined at 182 locations (including both ends of the transect). For each location, the CMR was measured at 6 points within an area of $50 \times 50$ $\mathrm{cm}$ (4 at individual corners and 2 in the center), irrespective of the vegetation of the points (plant species and plant parts), and the mean value was recorded as the CMR of the location. The area of $50 \times 50 \mathrm{~cm}$ was selected based on the feeding station (Coleman et al. 1989) of cattle used.

Immediately after the measurements of CMR along the transects, ten, $50 \times 50 \mathrm{~cm}$ locations whose CMR values covered the CMR range of the transects were selected in the paddock, avoiding the proximity of the transects, and the herbage was cut to a $3-\mathrm{cm}$ height. The samples were oven-dried at $85^{\circ} \mathrm{C}$ for 72 hours for dry matter determination. In Period 5, the number of samples was decreased to 5 to reduce labor requirement.

Calibration equations for estimating herbage mass (M, g DM $\left.\left(2500 \mathrm{~cm}^{2}\right)^{-1}\right)$ from CMR were developed fitting the following model to data:

$$
\mathrm{M}=\mathrm{a}_{0}+\mathrm{a}_{1} \times \mathrm{CMR}+\mathrm{a}_{2} \times \mathrm{CMR}^{2}
$$

where $\mathrm{a}_{0}, \mathrm{a}_{1}$ and $\mathrm{a}_{2}$ are constants. The independent variables, CMR and $\mathrm{CMR}^{2}$, were incorporated into the equation only when their partial regression coefficients $\left(a_{1}\right.$ and $a_{2}$, respectively) were significant ( $P$ 
$<0.05)$. Using the equation developed for each measurement occasion, the CMR at each location along the transects was converted into herbage mass (DM in an area of $50 \times 50 \mathrm{~cm}$ and above a height of $3 \mathrm{~cm}$ ).

Characteristics of the spatial distribution of herbage mass were expressed by the mean, minimum, maximum, SD and C.V. of data from the 182 locations along the transects. Similarity of the spatial patterns of herbage mass on 2 occasions was represented by a correlation coefficient $(n=182)$.

\section{Herbage accumulation}

Undisturbed herbage accumulation during each selected period was measured at 6 different herbage masses using exclosure cages $(1 \times 1 \mathrm{~m}$ in area and $75 \mathrm{~cm}$ in height), to develop the relationship between the accumulation rate and herbage mass (described later as Equation 2, also see Fig. 6 and Equations 4 to 8). At the beginning of each selected period, six, $50 \times 50 \mathrm{~cm}$ areas whose CMR values covered the CMR range of the transects at approximately equal intervals were selected in the paddock, avoiding the proximity of the transects, and the cages were placed on these areas. Then, the CMR of the areas was measured again 7 to 10 days after the end of the selected period. Initially, I intended to measure the final CMR at the end of the selected periods, but herbage accumulation during the 2 days was too small to detect with the capacitance probe. The initial and final CMR of each area was determined as the mean of 5 measurements (4 at individual corners and 1 in the center), and converted into herbage mass (DM in an area of $50 \times$ $50 \mathrm{~cm}$ and above a height of $3 \mathrm{~cm}$ ) as described above.

The rate of undisturbed herbage accumulation $\left(\mathrm{G}_{\text {undist }}\right.$, g DM $\left.\left(2500 \mathrm{~cm}^{2}\right)^{-1} \mathrm{~d}^{-1}\right)$ was related to the mean herbage mass during the accumulation period $\left(\mathrm{M}_{\text {mean }}, \mathrm{g} \mathrm{DM}\right.$ $\left.\left(2500 \mathrm{~cm}^{2}\right)^{-1}\right)$ assuming the following model:

$$
\mathrm{G}_{\text {undist }}=\mathrm{b}_{0}+\mathrm{b}_{1} \times \mathrm{M}_{\text {mean }}+\mathrm{b}_{2} \times \mathrm{M}_{\text {mean }}^{2}
$$

where $b_{0}, b_{1}$ and $b_{2}$ are constants. The independent variables, $\mathrm{M}_{\text {mean }}$ and $\mathrm{M}_{\text {mean }}{ }^{2}$, were selected in the same way as in Equation 1.

\section{Rate of defoliation}

Rate of defoliation or daily herbage consumption (D, g DM $\left.\left(2500 \mathrm{~cm}^{2}\right)^{-1} \mathrm{~d}^{-1}\right)$ at each location along the transects was calculated as:

$$
\mathrm{D}=\left(\mathrm{M}_{\text {pre }}-\mathrm{M}_{\text {post }}\right) / \mathrm{t}_{\mathrm{g}}+\mathrm{G}_{\text {dist }}
$$

where $M_{\text {pre }}$ and $M_{\text {post }}$ are respectively the

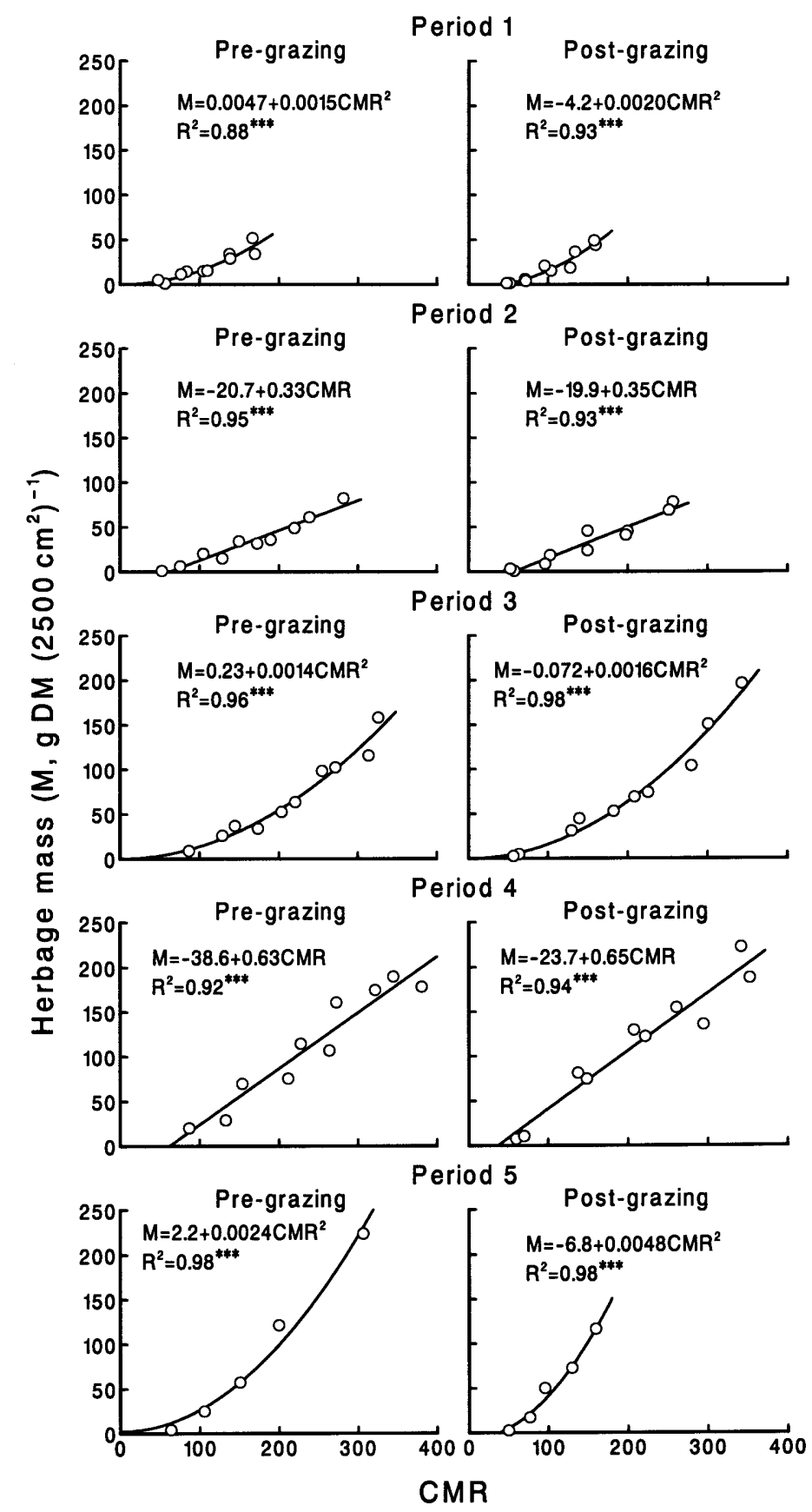

Fig. 2. Relationships between herbage mass and corrected meter reading (CMR) by an electronic capacitance probe. Three asterisks indicate significance at $\mathbf{P}<0.001$.

pre- and post-grazing herbage masses at the location $\left(\mathrm{g} \mathrm{DM}\left(2500 \mathrm{~cm}^{2}\right)^{-1}\right), \mathrm{t}_{\mathrm{g}}$ is the duration of the selected grazing period $(\mathrm{d})$, and $G_{\text {dist }}$ is the rate of disturbed herbage accumulation at the location during grazing $\left(\mathrm{g} \mathrm{DM}\left(2500 \mathrm{~cm}^{2}\right)^{-1} \mathrm{~d}^{-1}\right)$. The first term, $\left(\mathrm{M}_{\text {pre }}-\mathrm{M}_{\text {post }}\right) / \mathrm{t}_{\mathrm{g}}$, corresponds to the rate of decrease in herbage mass during grazing (apparent consumption). In this study, $\mathrm{t}_{\mathrm{g}}=2$ (Table 1$) . \mathrm{G}_{\text {dist }}$ was estimated from the mean herbage mass during the selected grazing period $\left(\mathrm{M}_{\text {mean }}=\left(\mathrm{M}_{\text {pre }}+\right.\right.$
$M_{\text {post }}$ /2) using Equation 2. Thus, the use of the model assumes that $\mathrm{G}_{\text {dist }}$, the rate of herbage accumulation under grazing, equals the rate of undisturbed herbage accumulation when the herbage mass is the same.

Characteristics of the spatial distribution of the rate of defoliation were expressed by the mean, minimum, maximum, SD and C.V. of data from the 182 locations along the transects. 


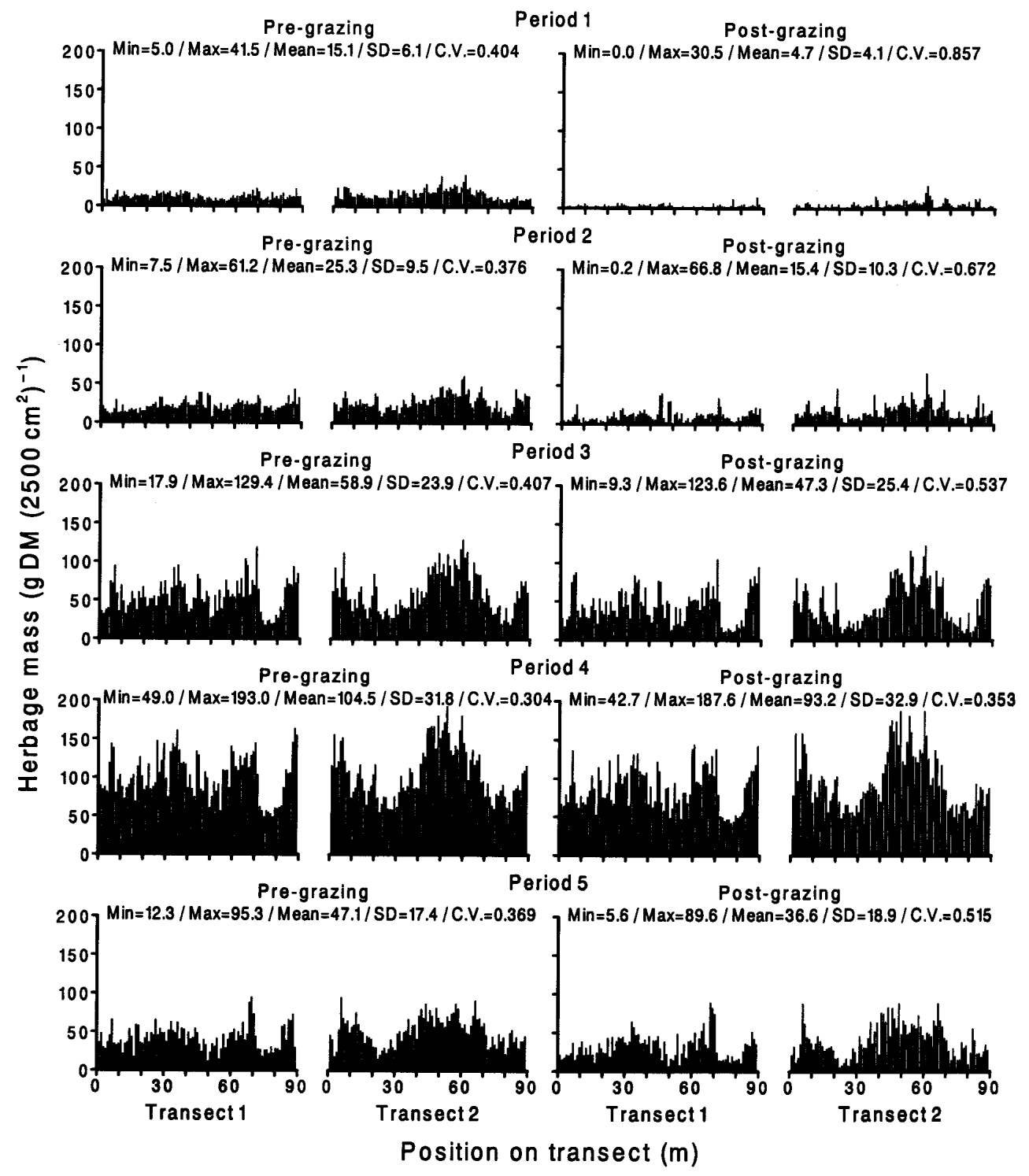

Fig. 3. Pre- and post-grazing distributions of herbage mass along the transects. The statistical parameters are minimum, maximum, mean, SD, and C.V.

\section{Results and Discussion}

\section{Labor requirement}

The present technique required a relatively small amount of labor. An operator of a capacitance probe and a recorder who also calculated the mean corrected meter reading $(C M R)$ at each location were enough for the measurements. It took approximately 2.5 hours for 2 persons to measure CMR at the 182 locations and in the 6 exclosures and collect 10 vegetation samples for developing a calibration equation. Reducing the number of samples to 5 in Period 5 shortened the time by approximately half an hour.

\section{Estimation of herbage mass}

Herbage mass was linearly or quadrati- cally related to CMR (Fig. 2). The linear and quadratic terms were not incorporated at the same time because their partial regression coefficients were not simultaneously significant $(\mathrm{P}>0.05)$. All the calibration equations were highly significant $\left(\mathrm{R}^{2}=\right.$ 0.88 to $0.98, \mathrm{P}<0.001)$ with $\mathrm{SE}$ of estimation of 4.4 to $16.8 \mathrm{~g} \mathrm{DM}\left(2500 \mathrm{~cm}^{2}\right)^{-1}$. The SE tended to be greater as the range of herbage mass broadened. Replacing the linear term by the quadratic term in Periods 1 , 3 , and 5 increased $R^{2}$ by 0.00 to 0.06 and decreased SE of estimation by 0.3 to $7.3 \mathrm{~g}$ DM $\left(2500 \mathrm{~cm}^{2}\right)^{-1}$. These results are similar to those from the previous study (Hirata et al. 1993). The slope of the line was always steeper, i.e., the regression coefficient was always greater, after grazing than before grazing. This may be mainly due to the decreased leaf to stem ratio of the sward with grazing.

\section{Heterogeneity in herbage mass}

Pre- and post-grazing herbage masses were spatially heterogeneous, as shown by the C.V. values of 0.304 to 0.857 (Fig. 3) With grazing, the mean and minimum herbage masses always decreased and, contrarily, C.V. always increased. Such an increase in C.V. with grazing accords with previous observations (Shiyomi et al. 1983, 1984, Hirata 1993a, 1993b, Liu and Hirata 1995, Hirata and Fukuyama 1997) and confirms that grazing by animals is a crucial factor in the development and maintenance of the heterogeneity (Bakker et al. 1983, Edwards et al. 1996).

There were always positive correlations between pre- and post-grazing herbage masses along the transects (Fig. 4). Furthermore, pre-grazing herbage mass in Periods 2 to 5 was always positively corre- 


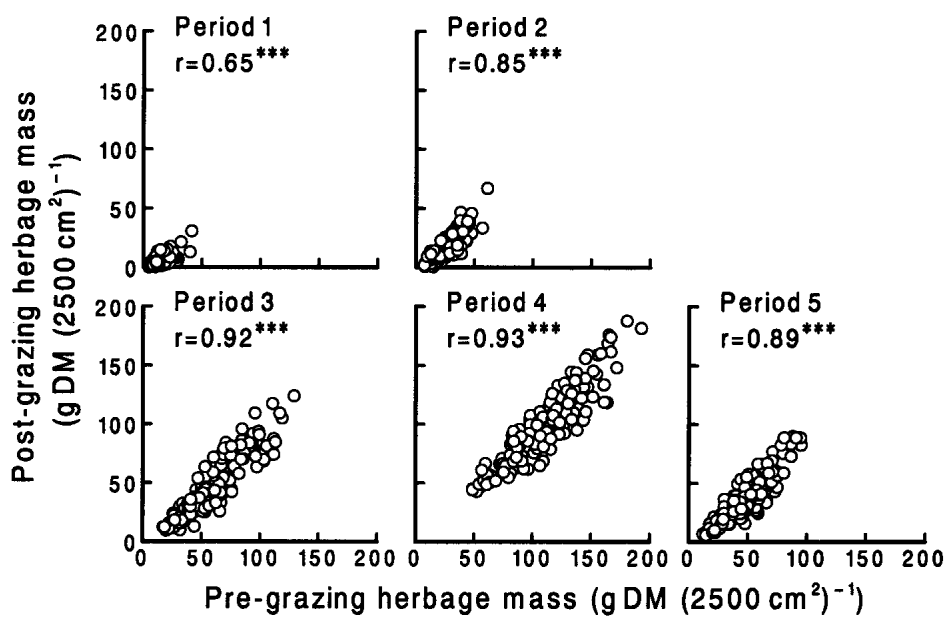

Fig. 4. Relationships between pre- and post-grazing herbage masses along the transects. Three asterisks indicate significance at $P<0.001$.

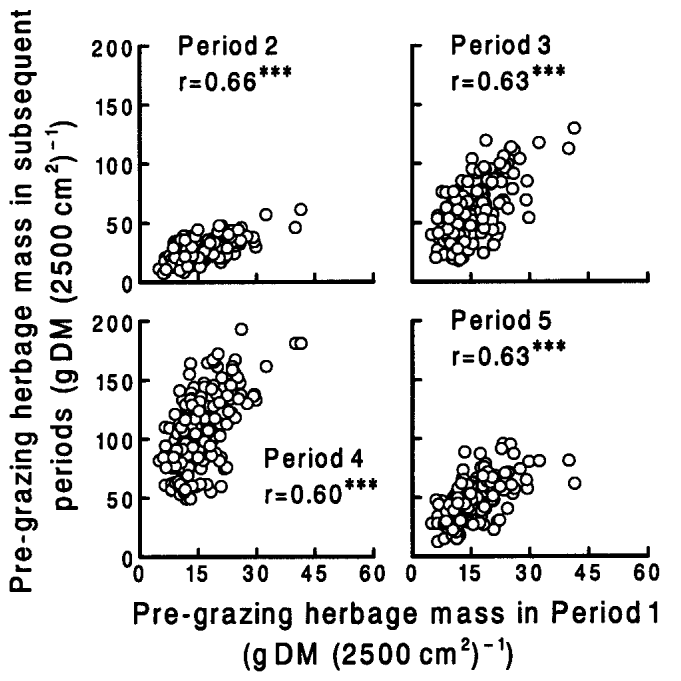

Fig. 5. Relationships between pre-grazing herbage masses along the transects in Period 1 and subsequent periods. Three asterisks indicate significance at $\mathbf{P}<0.001$. lated with that in Period 1 (Fig. 5). These results show that the spatial pattern of herbage mass was more or less stable at least for 5 months during the grazing season, which agrees with previous reports (Bakker et al. 1983, Willms et al. 1988, Cid and Brizuela 1998, Hirata 1998). The stability of the spatial pattern of herbage mass in the paddock during a 2 and a halfyear period has been investigated and discussed in Hirata (1998).

\section{Herbage accumulation during grazing}

The rate of undisturbed herbage accumulation $\left(\mathrm{G}_{\text {undist }}\right)$ was linearly or quadrati cally related to the mean herbage mass during the accumulation period $\left(\mathrm{M}_{\text {mean }}\right)$ (Fig. 6). The relationships in Periods 1, 2, 3,4 , and 5 were expressed by Equations 4, $5,6,7$, and 8 , respectively (SE given in brackets):

$\mathrm{G}_{\text {undist }}=0.117(0.055)+0.0203(0.0022) \mathrm{M}_{\text {mean }}$

$\left(\mathrm{R}^{2}=0.96, \mathrm{P}<0.001, \mathrm{SE}\right.$ of estimation $\left.=0.079\right)$

$\mathrm{G}_{\text {undist }}=0.575(0.452)+0.0299(0.0092) \mathrm{M}_{\text {mean }}$

$\left(\mathrm{R}^{2}=0.73, \mathrm{P}<0.05, \mathrm{SE}\right.$ of estimation $\left.=0.493\right)$

$\mathrm{G}_{\text {undist }}=-0.253(0.450)+0.0534(0.0104) \mathrm{M}_{\text {mean }}-2.61 \times 10^{-4}\left(0.50 \times 10^{-4}\right) \mathrm{M}_{\text {mean }}{ }^{2}$

$\left(\mathrm{R}^{2}=0.90, \mathrm{P}<0.05, \mathrm{SE}\right.$ of estimation $\left.=0.272\right)$

$\mathrm{G}_{\text {undist }}=0.307(0.150)+0.0207(0.0026) \mathrm{M}_{\text {mean }}-1.11 \times 10^{-4}\left(0.10 \times 10^{-4}\right) \mathrm{M}_{\text {mean }}{ }^{2}$ $\left(\mathrm{R}^{2}=0.99, \mathrm{P}<0.001, \mathrm{SE}\right.$ of estimation $\left.=0.041\right)$

$\mathrm{G}_{\text {undist }}=0.0029(0.0036)+0.00149(0.00011) \mathrm{M}_{\text {mean }}-7.65 \times 10^{-6}\left(0.66 \times 10^{-6}\right) \mathrm{M}_{\text {mean }}{ }^{2}$ $\left(\mathrm{R}^{2}=0.99, \mathrm{P}<0.01, \mathrm{SE}\right.$ of estimation $\left.=0.003\right)$

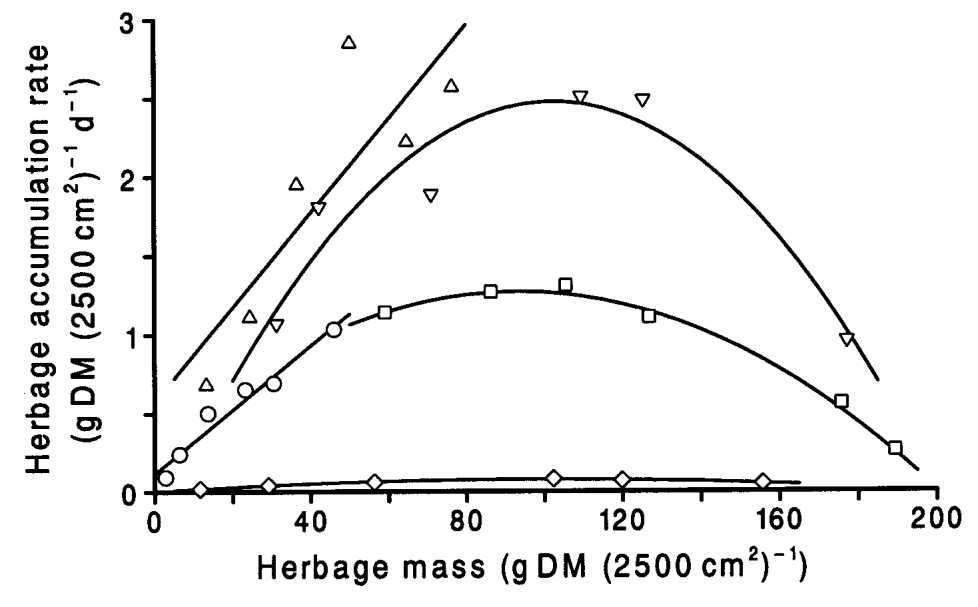

Fig. 6. Relationships between rate of undisturbed herbage accumulation and mean herbage mass in Periods $1(\bigcirc), 2(\Delta), 3(\nabla), 4(\square)$, and $5(\diamond)$. See text for equations.
Periods 1 and 2, apparently caused by the low, narrow ranges of $\mathrm{M}_{\text {mean }}$. The quadratic relationship between growth rate and herbage mass which produces the logistic growth agrees with models developed by Noy-Meir (1978) and Hart (1989).

\section{Heterogeneity in herbage consump- tion}

The rate of defoliation was spatially heterogeneous, as shown by the C.V. values of 0.428 to 0.904 (Fig. 7). The heterogeneity (C.V.) tended to increase as the mean pre-grazing herbage mass increased (Fig. 3) $(\mathrm{r}=0.87, \mathrm{P} \approx 0.05)$. This phenomenon reflects the fact that animals are more selective and patch grazing is more prevalent under lower grazing pressure (Willms et al. 1988, Vallentine 1990, Cid and Brizuela 1998). In the present study, high- 
Period 1

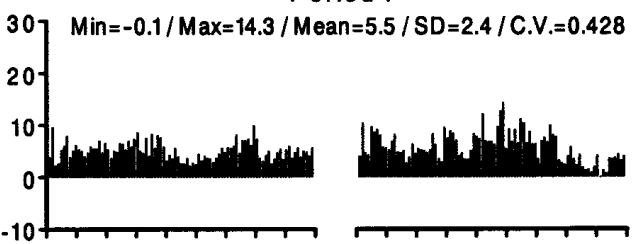

Period 2

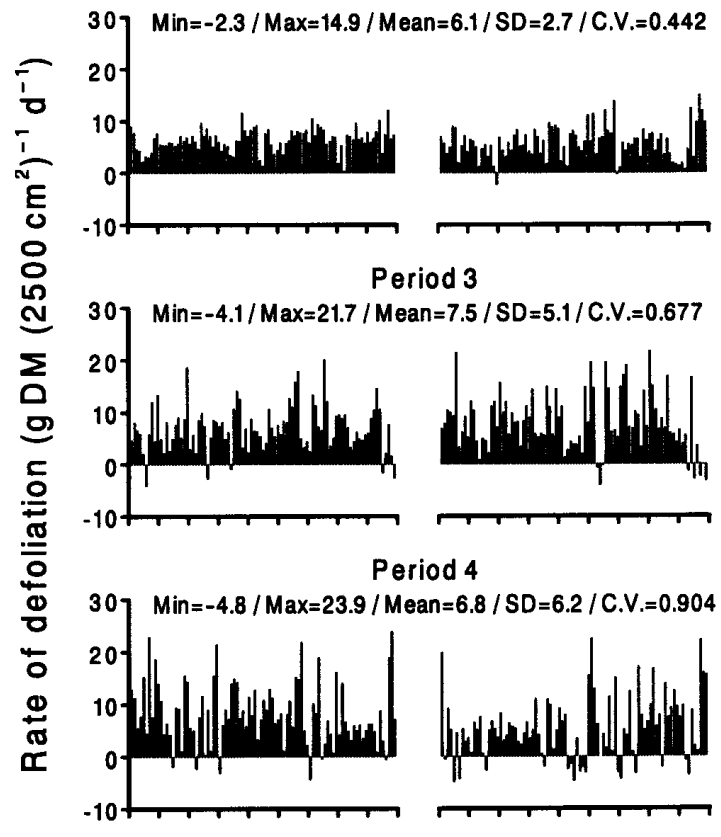

Period 5

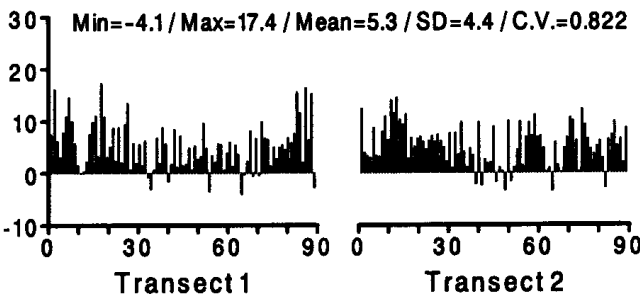

Position on transect $(\mathrm{m})$

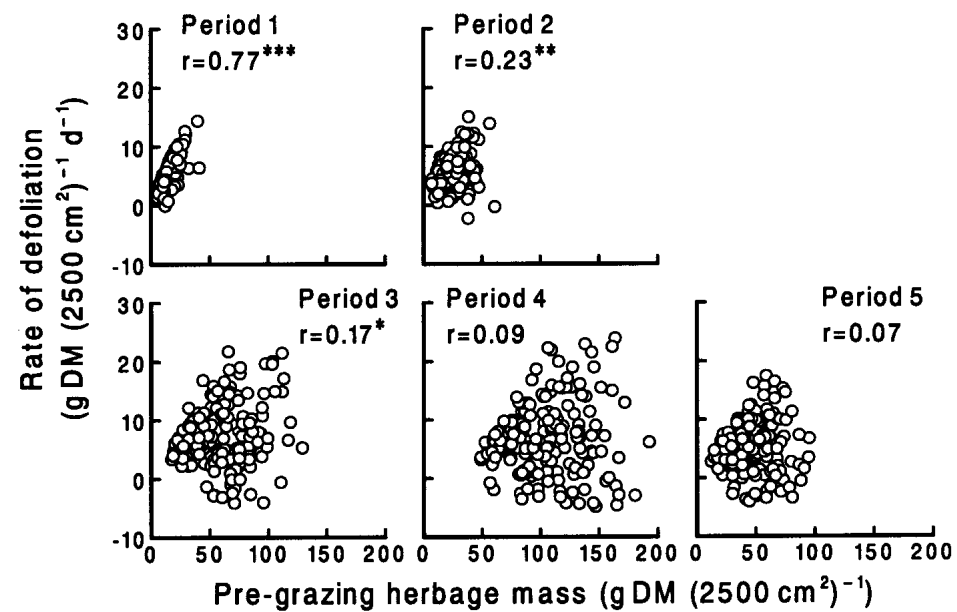

Fig. 8. Relationships between rate of defoliation and pre-grazing herbage mass along the transects. One, 2 , and 3 asterisks indicate significance at $\mathrm{P}<0.05, \mathrm{P}<0.01$, and $\mathrm{P}<0.001$, respectively.

frequently than the locations with higher herbage mass. Further studies are therefore necessary to relate herbage consumption at individual locations to ingestive behavior of animals such as the number of visits, residence time, biting rate and bite weight.

Calculation of the rate of defoliation (Equation 3) sometimes produced negative values (Figs. 7 and 8). From the components of Equation 3, the negative values of the rate of defoliation are first attributable to the errors of estimation of $\mathrm{M}_{\text {pre }}, \mathrm{M}_{\text {post }}$ and/or $\mathrm{G}_{\text {dist }}$. The errors in $\mathrm{G}_{\mathrm{dist}}$ are further attributable to the errors of $M_{\text {pre }}$, $M_{\text {post }}$ and/or Equations 4 to 8 (Fig. 6), because $\mathrm{G}_{\text {dist }}$ was er mean herbage mass coincided with lower grazing pressure because the paddock size was fixed and the number of animals and their mean liveweight were almost constant throughout (Table 1).

There were positive correlations between the rate of defoliation and pregrazing herbage mass along the transects in Periods 1, 2 and 3, and no significant correlations in other periods (Fig. 8). This fact shows that animals did not consume more from the locations with lower herbage mass. Because the current study did not measure ingestive behavior of animals, it is unknown whether the animals visited the locations with lower herbage mass more mass but also in other aspects such as leaf area, soil fertility and influences of treading and feces and urine deposition by animals. The errors in Equations 4 to 8 are taken to partly reflect these limitations. In addition, the periods during which the undisturbed herbage accumulation was measured were 7 to 10 days longer than the selected 2-day periods.

Despite these limitations, no better technique was available for estimating the preand post-grazing herbage masses and the rate of disturbed herbage accumulation at the 182 locations individually, nondestructively and rapidly. Furthermore, the negative values of herbage consumption (Figs. 7 and 8) were not replaced by zero, because the replacement would produce some bias in the data as a whole.

One may question the reliability of the present technique in estimating the location and intensity of grazing by the animals, on the grounds that I did not observe whether or not the locations were actually grazed. However, the way in which the rate of defoliation was calculated (Equation 3), i.e., as the sum of the rate of net defoliation $\left(\left(\mathrm{M}_{\text {pre }}-\mathrm{M}_{\text {post }}\right) / \mathrm{t}_{\mathrm{g}}\right)$ and the rate of disturbed herbage accumulation $\left(\mathrm{G}_{\text {dist }}\right)$, is normally used to estimate herbage consumption on a basis of a whole pasture (Meijs et al. 1982).

The present technique may also be supported by the mean rate of defoliation along the transects (Fig. 7). The daily herbage intake by the animals that was calculated from the mean rate of defoliation, the paddock area, and the number and mean liveweight of animals (Table 1) was 18.0, 20.4, 25.4, 22.0, and 14.9 g DM 
$(\mathrm{kg} \mathrm{LW})^{-1} \mathrm{~d}^{-1}$ for Periods 1, 2, 3, 4, and 5, respectively. These values agree closely with the grazing intake of Japanese Black Cows (AFFRCS 1995) when the mean pre-grazing herbage mass (Fig. 3) and the digestibility of a bahia grass pasture (Higashiyama and Hirata 1995) are taken into account.

Furthermore, the present technique, owing to the large number of data sets from the pasture $(n=182)$, is considered to give reliable trends of spatial distribution of herbage consumption. An example is the increase in the spatial heterogeneity in herbage consumption with the increased mean pre-grazing herbage mass (Figs. 3 and 7) as discussed above. We can understand which locations of the pasture were heavily defoliated or lightly defoliated. Because of the small labor requirement, it may be possible to establish more locations for measurements so that they can cover the whole area of a pasture.

\section{Conclusions}

Previous studies have mainly used 2 techniques for quantifying the spatial heterogeneity in vegetation in grazed pastures. One is a random sampling of sward height (Gibb and Ridout 1986,1988) or herbage mass (Shiyomi et al.1983,1984, Hirata 1993a) from a pasture, and the other is a monitoring of degree of utilization (Bakker et al. 1983, Willms et al. 1988, Cid and Brizuela 1998) or sward height (Edwards et al. 1996) in some permanent areas in a pasture. The latter technique is advantageous over the former because it can follow the temporal dynamics in vegetation characteristics in the same locations in a pasture and therefore can estimate the patch stability. However, few workers have used the latter technique to monitor herbage mass, i.e., a most important vegetation characteristic, because estimation of herbage mass normally requires destructive sampling.

The present technique, by using an electronic capacitance probe, can follow the temporal dynamics in herbage mass in a number of fixed locations in a pasture with a relatively small amount of labor. Spatial heterogeneity in herbage mass and the stability of the spatial pattern of herbage mass were well quantified (Figs. 3 to 5). Spatial heterogeneity in the rate of defoliation was also well quantified in spite of some negative values (Fig. 7). The present technique is therefore considered to be of potential value for quantifying the spatial heterogeneity in herbage mass and con- sumption by animals in grazed pastures, though further studies are necessary for testing the applicability of the technique to pastures of other plant species or of multiple species.

\section{Literature Cited}

[AFFRCS] Agriculture, Forestry and Fisheries Research Council Secretariat. 1995. Japanese feeding standard for beef cattle (1995). Central Association of Livestock Industry, Tokyo, Japan.

Bakker, J.P., J. de Leeuw, and S.E. van Wieren. 1983. Micro-patterns in grassland vegetation created and sustained by sheep grazing. Vegetatio 55:153-161.

Cid, M.S. and M.A. Brizuela. 1998 Heterogeneity in tall fescue pastures created and sustained by cattle grazing. J. Range Manage. 51:644-649.

Coleman, S.W., T.D.A. Forbes, and J.W. Stuth 1989. Measurements of the plant-animal interface in grazing research. p. 37-51. In: G.C. Marten (ed.), Grazing research: design, methodology, and analysis. Crop Sci. Soc. of Amer. and Amer. Soc. of Agron., Madison, Wis

Edwards, G.R., A.J. Parsons, J.A. Newman, and I.A. Wright. 1996. The spatial pattern of vegetation in cut and grazed grass/white clover pastures. Grass Forage Sci. 51:219-231.

Frame, J. 1993. Herbage mass. p. 39-67. In: A. Davies, R.D. Baker, S.A. Grant, and A.S Laidlaw (eds.), Sward measurement handbook (2nd ed.). Brit. Grassl. Soc., Reading, UK

Gibb, M.J. and M.S. Ridout. 1986. The fitting of frequency distributions to height measurements on grazed swards. Grass Forage Sci. 41:247-249.

Gibb, M.J. and M.S. Ridout. 1988 . Application of double normal frequency distributions fitted to measurements of sward height. Grass Forage Sci. 43:131-136.

Hart, R.H. 1989. SMART: A simple model to assess range technology. J. Range Manage. 42:421-424.

Higashiyama, M. and M. Hirata. 1995. Analysis of a Japanese Black Cattle rearing system utilizing a bahiagrass (Paspalum notatum Flügge) pasture. 1. Variations in the factors considered to affect animal production. Grassl. Sci. 41:104-113.

Hirata, M. 1993a. Changes in the variations in herbage mass of bahiagrass (Paspalum nota tum Flügge) pasture with the grazing by dairy heifers. Bull. Fac. Agr., Miyazaki Univ. 40:1-5.

Hirata, M. 1993b. Distribution of herbage mass in bahiagrass (Paspalum notatum Flügge) pasture as affected by grazing by beef cattle, mowing, paddock area and season. Bull. Fac. Agr., Miyazaki Univ. 40:91-98.

Hirata, M. 1998. Dynamics of the horizontal distribution of herbage mass in a bahiagrass
(Paspalum notatum Flügge) pasture grazed by cattle: Stability of spatial pattern of herbage mass. Grassl. Sci. 44:169-172.

Hirata, M. and K. Fukuyama. 1997. Dynamics of the horizontal distribution of herbage mass in a bahiagrass (Paspalum notatum Flügge) pasture with grazing by cattle. Grassl. Sci. 43:1-6.

Hirata, M., M. Higashiyama, M. Kikuchi, and S. Liu. 1993. Estimation of herbage mass of bahiagrass (Paspalum notatum Flügge) swards with an electronic capacitance meter. Bull. Fac. Agr., Miyazaki Univ. 40:83-89.

Illius, A.W., D.G.M. Wood-Gush, and J.C. Eddison. 1987. A study of the foraging behaviour of cattle grazing patchy swards. Biol. Behav. 12:33-44.

Liu, S. and M. Hirata. 1995. Spatial distribution of herbage mass in bahiagrass (Paspalum notatum Flügge) pasture under grazing, resting and mowing. J. Japan. Grassl. Sci. 40:457-470.

Meijs, J.A.C., R.J.K. Walters, and A. Keen. 1982. Sward methods. p. 11-36. In: J.D. Leaver (ed.), Herbage intake handbook. Brit. Grassl. Soc., Maidenhead, UK.

Noy-Meir, I. 1978. Grazing and production in seasonal pastures: Analysis of a simple model. J. Applied Ecol. 15:809-835.

Shiyomi, M., T. Akiyama, and S. Takahashi. 1983. A spatial pattern model of plant biomass in grazing pasture I. J. Japan. Grassl. Sci. 28:373-382.

Shiyomi, M., T. Akiyama, and S. Takahashi. 1984. A spatial pattern model of plant biomass in grazing pasture II. J. Japan. Grassl. Sci. 30:40-48.

Vallentine, J.F. 1990. Grazing management Academic Press, San Diego, Calif.

Willms, W.D., J.F. Dormaar, and G.B. Schaalje. 1988. Stability of grazed patches on rough fescue grasslands. J. Range Manage. 41:503-508. 